EGU2020-18752

https://doi.org/10.5194/egusphere-egu2020-18752

EGU General Assembly 2020

(c) Author(s) 2020. This work is distributed under

the Creative Commons Attribution 4.0 License.

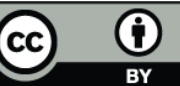

\title{
High-resolution reconstruction of extreme hydrological events occurred in the Douro River estuary (Portugal, Iberian Northwest) during the 19th century
}

Inês Amorim, Luís Sousa Silva, and João Carlos Garcia

University of Porto, Portugal, CITCEM, Department of History and of Political and International Studies, Porto, Portugal (inesamorimflup@gmail.com)

Flood historical records are important to place current flooding events into a long-term perspective. With these data sets it is possible to identify patterns in past recent floods and use these to characterize and model future floods. In what concerns to Portugal, some studies had already used some documentary evidence in order to reconstruct flood events, in particular centered in the year 1786 that was the rainiest in Portugal, triggering floods in northwestern and central Portugal, followed by a extremely wet and rainfall 1788 year that caused floods along the largest Iberian rivers: Douro, Mondego and Tagus. However, very little is known about the characteristics of these events prior to the beginning of regular meteorological/hydrological observations (late $19^{\text {th }}$ century in Portugal).

Within this framework, we aim to reconstruct a high-resolution history of floods occurred on the estuary of the Douro River (near the city of Porto, Portugal, Iberian' Northwest) during the $19^{\text {th }}$ century. The Douro River is the third-longest river in the Iberian Peninsula (after the Tagus and the Ebro rivers) and it drains an area of 97.600 square kilometers (the most largely in the Iberian Peninsula). To achieve our main aim, early instrumental observations and documentary evidence from multiple archival sources were collected. Further, the flooding archive was used to make a serial analysis of the years of floods, their chronological distribution, frequency, duration and intensity, associated with meteorological phenomena and their impacts. 